\title{
PROCESSING OF SODIUM-POTASSIUM NIOBATE CERAMICS
}

Bob R. Powell, Jr.

(M.S. Thesis)

December 2, 1971

AEC Contract No. W-7405-eng-48 
PROCESSING OF SODIUM-POTASSIUM NIOBATE CERAMICS

I. INTRODUCTION . . . . . . . . . . . . . . . . . . . I

II. EXPERIMENTAL ................ 6

A. Preparation of Powders for Calcining . . . . . 6

B. Calcining and the Reaction Studies . . . . . 9

C. Sintering Studies ............. 14

III. RESULTS AND DISCUSSION . . . . . . . . . . . . . 17

A. Calcining Reactions . . . . . . . . . . 17

B. Sintering Phenomenon ........... . 24

IV. CONCLUSION .................. . . 35

ACKNOWLEDGMENTS . . . . . . . . . . . . . 36

REFERENCES ..................... 37 
PROCESSING OF SODIUM-POTASSIUM NIOBATE CERAMICS

Bob R. Powell, Jr.

Inorganic Materials Research Division, Lawrence Berkeley Laboratory and Department of Materials Science and Engineering, College of Engineering; University of California, Berkeley, California 94720

ABSTRACT

Sintering studies of undoped $\left(\mathrm{Na}_{0} \cdot{ }_{5} \mathrm{~K}_{0} \cdot{ }_{5}\right) \mathrm{NbO}_{3}$ and the same material doped with $1 / 2,1,2$, and 4 mole percent $\mathrm{BaO}$ and 2 mole $\% \mathrm{~B}_{2} \mathrm{O}_{3}$ were made. The persistance of a second phase after calcining to form the compound led to a study of reactions occurring during calcination. The calcining of sodium-potassium niobates involves the formation of an intermediate compound (the second phase) and its subsequent reaction with sodium oxide and potassium oxide to form $\left(\mathrm{Na}_{0} \cdot{ }_{5} \mathrm{~K}_{0} \cdot{ }_{5}\right) \mathrm{NbO}_{3}$. Sintering data show that up to $1 / 2$ mole $\% \mathrm{BaO}$ added to the system increases the initial densification. However, the sintered bodies then exhibit densification and form sharp cubic grains and large voids. Indications are that a liquid phase is the major contributor to densification of this system through the mechanism of particle rearrangement, and that the contribution of any sintering mechanism to densification is negligible. 


\section{INTRODUCTION}

Sodium-potassium niobate (henceforth referred to as NKN) is a perovskite ferroelectric ceramic that has found extensive use in the production of ultrasonic delay lines. ${ }^{1}$ NKN is the name given to the solid solution having equal mole percents of sodium niobate and potassium niobate. Sodium niobate and potassium niobate form a complete solid solution series having a low dielectric constant. At the equal mole percent composition the electromechanical coupling coefficient is a maximum, 0.34 to 0.39 at room temperature. ${ }^{2}$ It is the low dielectric constant that makes NKN particularly useful in "high" frequency applications while it is the high coupling coefficient that is necessary for transducers.

Obtaining pure, high density NKN, is usually accomplished by hotpressing. $^{3} \mathrm{NKN}$ is produced when raw materials are calcined to bring about the following reaction:

$$
1 / 4 \mathrm{Na}_{2} \mathrm{CO}_{3}+1 / 4 \mathrm{~K}_{2} \mathrm{CO}_{3}+1 / 2 \mathrm{Nb}_{2} \mathrm{O}_{5} \rightarrow\left(\mathrm{Na}_{0} \cdot{ }_{5} \mathrm{~K}_{0} \cdot 5\right) \mathrm{NbO}_{3}+1 / 2 \mathrm{CO}_{2}
$$

However, it is important to note that the common practice for preparing the above batch for calcining is to add small amounts (up to 2 mole \%) excess of each carbonate. Egerton and Dillon ${ }^{2}$ added 0.1 mole \% excess while Stannek ${ }^{4}$ added 1.5 mole $\%$ excess of each carbonate. Stannek explained that this was done to eliminate the formation of a second phase, $(\mathrm{NaK}) \mathrm{Nb}_{8} \mathrm{O}_{21}$ which formed during calcination of the stoichiometrically mixed materials. Stannek also tried nitrates as starting materials and found that the second phase could be eliminated by adding 1.3 mole \% 
excess of each nitrate.

Nitrates have the advantage over carbonates of decomposing at lower temperatures, about $400^{\circ} \mathrm{C}$ for sodium nitrate and potassium nitrate as compared to about $870^{\circ} \mathrm{C}$ for the respective carbonates. In addition, the nitrates are very soluble in water and as a result, liquid-solid mixing can be used if an evaporation technique is used to remove the water. Also, the degree of mixing is less critical for the nitrates because they melt eutectically at $224^{\circ} \mathrm{C}^{5}$ to form a viscous liquid which should coat all the niobium pentoxide particles.

Calcining results in Stannek's work and this study for nitrateprepared NKN showed a second phase. The concentration of the second phase increased toward the interior of a calcined compact of the mixed oxides. The reactions occurring during calcination are unknown, so a study was undertaken to determine them. Little is actually known of the structure of the sodium-potassium niobate compounds. Stannek ${ }^{4}$ indexed the pattern for pure NKN but X-ray patterms for other compounds in the sodium oxide-potassium oxide-niobium pentoxide phase diagrams have to be determined from the X-ray patterns of the single alkali oxide-niobium pentoxide compounds. Of these, the system $\mathrm{Na}_{2} \mathrm{O}-\mathrm{Nb}_{2} \mathrm{O}_{5}$ has been studied extensively ${ }^{6,7}$ and for this reason the calcining reactions in this system were studied. The effects of solid solution of potassium into the system should not change the reactions. The $\mathrm{Na}_{2} \mathrm{O}-\mathrm{Nb}_{2} \mathrm{O}_{5}$. phase diagram as determined by Shafer and Roy ${ }^{6}$ is shown in Fig. 1.

The complete $(\mathrm{NaK}) \mathrm{O}-\mathrm{Nb}_{2} \mathrm{O}_{5}$ phase diagram has not been determined, but from the data of Reisman and Banks, ${ }^{8}$ Shafer and Roy, ${ }^{6}$ and Reisman and Holtzberg, ${ }^{9}$ an approximate phase diagram for the system in the 


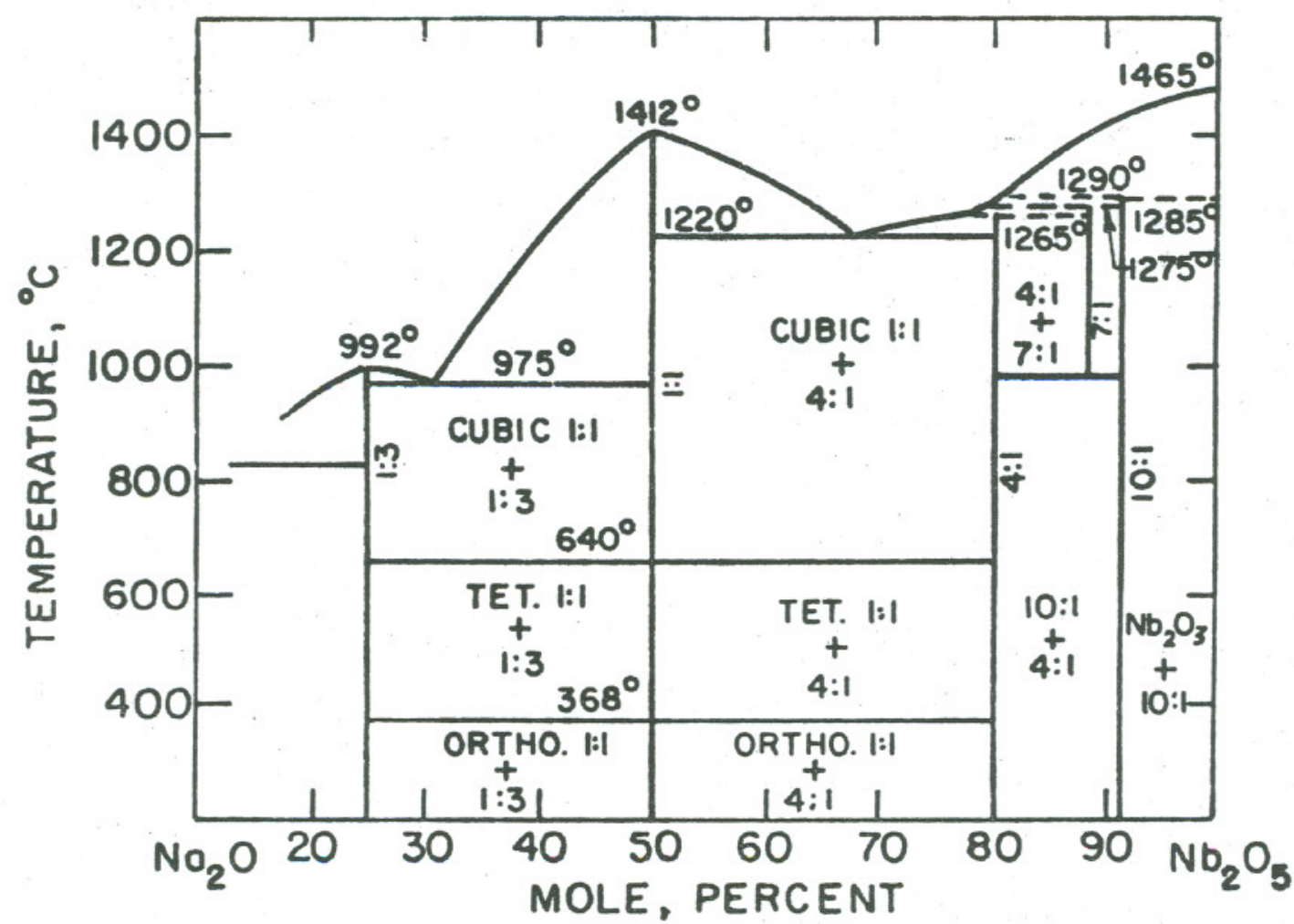

XBL 707-1465

Fig. 1. Phase diagrams of the system $\mathrm{Na}_{2} \mathrm{O}-\mathrm{Nb}_{2} \mathrm{O}_{5}$ (Ref. 6). 
region of interest was extrapolated, and is shown in Fig. 2. From the diagram it is clear that a small deviation from stoichiometry causes a large change in the alkali metal oxide activity. This is shown schematically in Fig. 2.

Sintering of NKN is difficult. To date, all industrially produced NKN is hot-pressed. ${ }^{10,11}$ Conventional sintering is the most economic method because it requires less elaborate equipment and is more applicable to producing large volumes of material. For NKN it has not been possible to obtain high density samples using conventional sintering. Stannek ${ }^{4}$ tried varying the parameters of sintering and was able to reach $94 \%$ of theoretical density. He varied atmosphere, time, temperature and tried doping NKN with varying amounts of $\mathrm{BaO}$. In some cases de-denisification was noted.

$\mathrm{BaO}$ was added as a dopant to reduce grain growth. The atmosphere also had a significant effect. Stannek's optimum sintering curves were obtained with 0.5 mole percent $\mathrm{BaO}$ at $1100^{\circ} \mathrm{C}$ in an oxygen atmosphere and a packing powder having excess $\mathrm{Nb}_{2} \mathrm{O}_{5}$ (low alkali activity). This was for material prepared from nitrates of sodium and potassium.

It was the purpose of this work to continue the study of the processing steps leading to pure nitrate prepared NKN and the sintering of it.
\end{abstract}



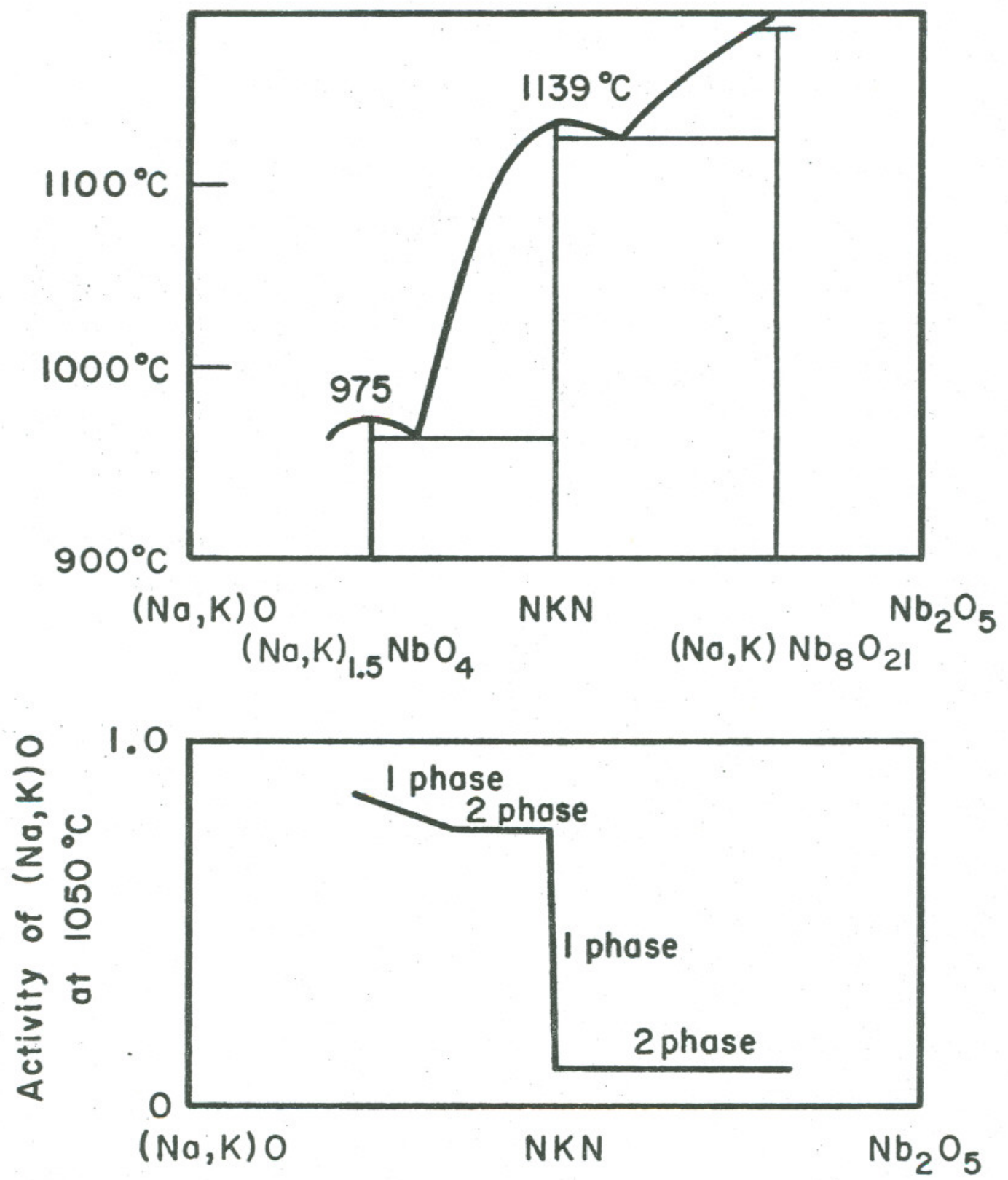

$X B L 7111-4745$

Fig. 2. Approximate phase diagram for the system ( $\mathrm{NaK}) \mathrm{O}-\mathrm{Nb}_{2} \mathrm{O}_{5}$ with schematic of alkali activity. 


\section{EXPERIMENTAL}

\section{A. Preparation of Powders for Calcining}

The nitrate compounds used were supplied by J. T. Baker Chemical Company while the niobium pentoxide came from Atomergic Chemetals Company. The impurity of each nitrate compound is shown in Table I.

The powder preparation method used was dry mixing. Before weighing, the materials were kept in a dryer for 50 hours. NKN was made in one mole batches according to the reaction:

$1 / 2 \mathrm{NaNO}_{3}+1 / 2 \mathrm{KNO}_{3}+1 / 2 \mathrm{Nb}_{2} \mathrm{O}_{5} \rightarrow\left(\mathrm{Na}_{0} \cdot{ }_{5} \mathrm{~K} 0 \cdot 5\right) \mathrm{NbO}_{3}+\mathrm{NO}_{2}+1 / 4 \mathrm{O}_{2}$

Mixing was done in a polyethylene container with teflon media. Mixing time was 24 hours. Next, the mixed powders were fired in air for 20 hours at $450^{\circ} \mathrm{C}$ to eliminate organic impurities picked up during processing. This created a liquid phase which caused the particles to agglomerate. Further grinding was not needed because the liquid phase reformed during calcining and intimate contact between nitrate and $\mathrm{Nb}_{2} \mathrm{O}_{5}$ particles was maintained.

To produce doped NKN for sintering, $\mathrm{Ba}\left(\mathrm{NO}_{3}\right)_{2}$ was used. From ionic radii data it is believed that $\mathrm{Ba}^{+2}$ substitutes for either $\mathrm{Na}^{+}$or $\mathrm{K}^{+}$ in the perovskite lattice, the A-sites (see Fig. 3). For each $\mathrm{Ba}^{+2}$ ion that is substituted, a vacancy of either $\mathrm{Na}^{+}$or $\mathrm{K}^{+}$occurs. The reaction for producing 1.0 mole \% $\mathrm{BaO}$ doped $\mathrm{NKN}$ is: 
Table I. Impurity levels in nitrate compounds

\begin{tabular}{|c|c|c|c|}
\hline & $\begin{array}{c}\mathrm{KNO}_{3} \\
\text { Baker's reagent } \\
\text { grade } \\
99.9 \text { wt\% }\end{array}$ & $\begin{array}{c}\mathrm{NaNO}_{3} \\
\text { Baker's reagent } \\
\text { grade } \\
99.6 \mathrm{wt} \%\end{array}$ & $\begin{array}{c}\mathrm{Ba}\left(\mathrm{NO}_{3}\right)_{2} \\
\text { Baker's reagent } \\
\text { grade } \\
99.9 \text { wt\% }\end{array}$ \\
\hline $\mathrm{Cl}$ & 0.002 & 0.001 & 0.001 \\
\hline $\mathrm{IO}_{3}$ & $<0.0005$ & $<0.0005$ & - \\
\hline $\mathrm{NO}_{2}$ & $<0.001$ & $<0.001$ & - \\
\hline $\mathrm{PO}_{4}$ & 0.0001 & 0.0002 & - \\
\hline $\mathrm{SO}_{4}$ & 0.0005 & 0.001 & - \\
\hline $\mathrm{Ca}, \mathrm{Mg}$ & 0.005 & 0.002 & 0.04 \\
\hline Heavy metals & 0.0002 & 0.0002 & 0.0001 \\
\hline $\mathrm{Fe}$ & 0.0001 & 0.0001 & 0.00005 \\
\hline $\mathrm{Na}$ & 0.003 & - & - \\
\hline K & - & 0.004 & - \\
\hline $\mathrm{Sv}$ & - & - & 0.5 \\
\hline
\end{tabular}




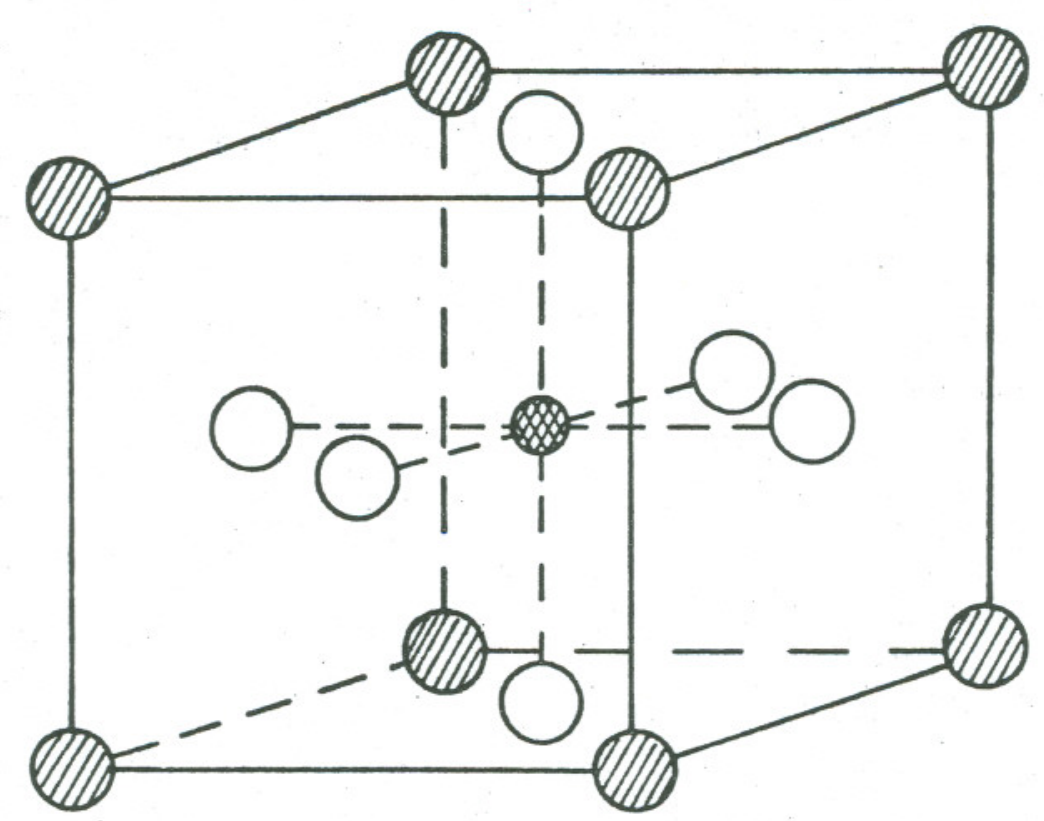

CUBIC PEROVSKITE STRUCTURE

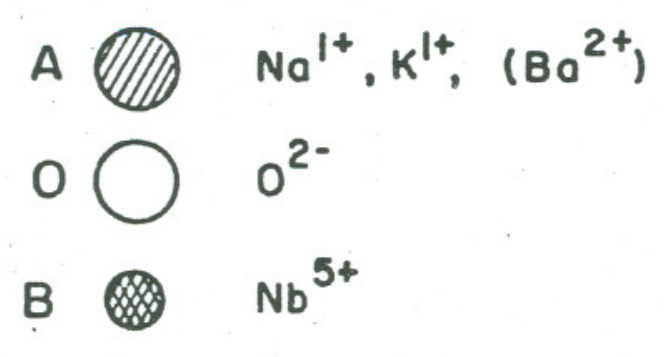

XBL 707-1452

Fig. 3. Unit cell structure of perovskite $\left(\mathrm{Na}_{0} \cdot{ }_{5} \mathrm{~K}_{0} \cdot 5\right) \mathrm{NbO}_{3}$. 


$$
\begin{gathered}
-9- \\
0.49 \mathrm{NaNO}_{3}+0.49 \mathrm{KNO}_{3}+0.01 \mathrm{Ba}\left(\mathrm{NO}_{3}\right)_{2}+0.5 \mathrm{Nb}_{2} \mathrm{O}_{5} \\
\rightarrow\left(\mathrm{Na}_{0} .{ }_{49} \mathrm{~K}_{0.49}\right) \mathrm{Ba}_{0.01} \square_{0.01} \mathrm{NbO}_{3}+\mathrm{NO}_{2}+1 / 4 \mathrm{O}_{2}
\end{gathered}
$$

One-tenth mole doped batches of NKN were made for:

$$
\begin{aligned}
& \left(\mathrm{Na}_{0.495} \mathrm{~K}_{0.495}\right) \mathrm{B}_{0.005} \square_{0.005} \mathrm{NbO}_{3} \\
& \left(\mathrm{Na}_{0}{ }_{49} \mathrm{~K}_{0.49}\right) \mathrm{Ba}_{0.01} \square 0.0{ }_{1} \mathrm{NbO}_{3} \\
& \left(\mathrm{Na}_{0}{ }_{48} \mathrm{~K}_{0} .{ }_{48}\right) \mathrm{Ba}_{0} .02 \square 0.02 \mathrm{NbO}_{3} \\
& \left(\mathrm{Na}_{0.46} \mathrm{~K}_{0} .46\right) \mathrm{Ba}_{0} .04 \square 0.04 \mathrm{NbO}_{3}
\end{aligned}
$$

Mixtures of $\mathrm{NaiNO}_{3}$ and $\mathrm{Nb}_{2} \mathrm{O}_{5}$ were produced to yield compounds of:

$$
\begin{aligned}
& \mathrm{Na}_{2} \mathrm{Nb}_{8} \mathrm{O}_{21} \\
& \mathrm{Na}_{2} \mathrm{Nb}_{20} \mathrm{O}_{51} \\
& \mathrm{NaNbO}_{3} \\
& \mathrm{Na}_{3} \mathrm{NbO}_{4}
\end{aligned}
$$

\section{B. Calcining and the Reaction Studies}

Calcining was done in air and oxygen at $850^{\circ} \mathrm{C}$ for two hours. This time and temperature was selected because Stannek ${ }^{4}$ found it to be optimum for his carbonates. Crystal phases in the fired powder was checked using X-ray diffraction analysis.

For the first calcining runs, small amounts of NKN were loosely placed in the bottom of a covered platinum crucible. The results of X-ray analysis showed single phase $\mathrm{NKN}$. Later larger quantities of powder and cold pressed one inch diameter, one inch high pellets were calcined. The results for the powder are shown in Fig. 4. The concentration of the second phase increased as the interior of the system was 


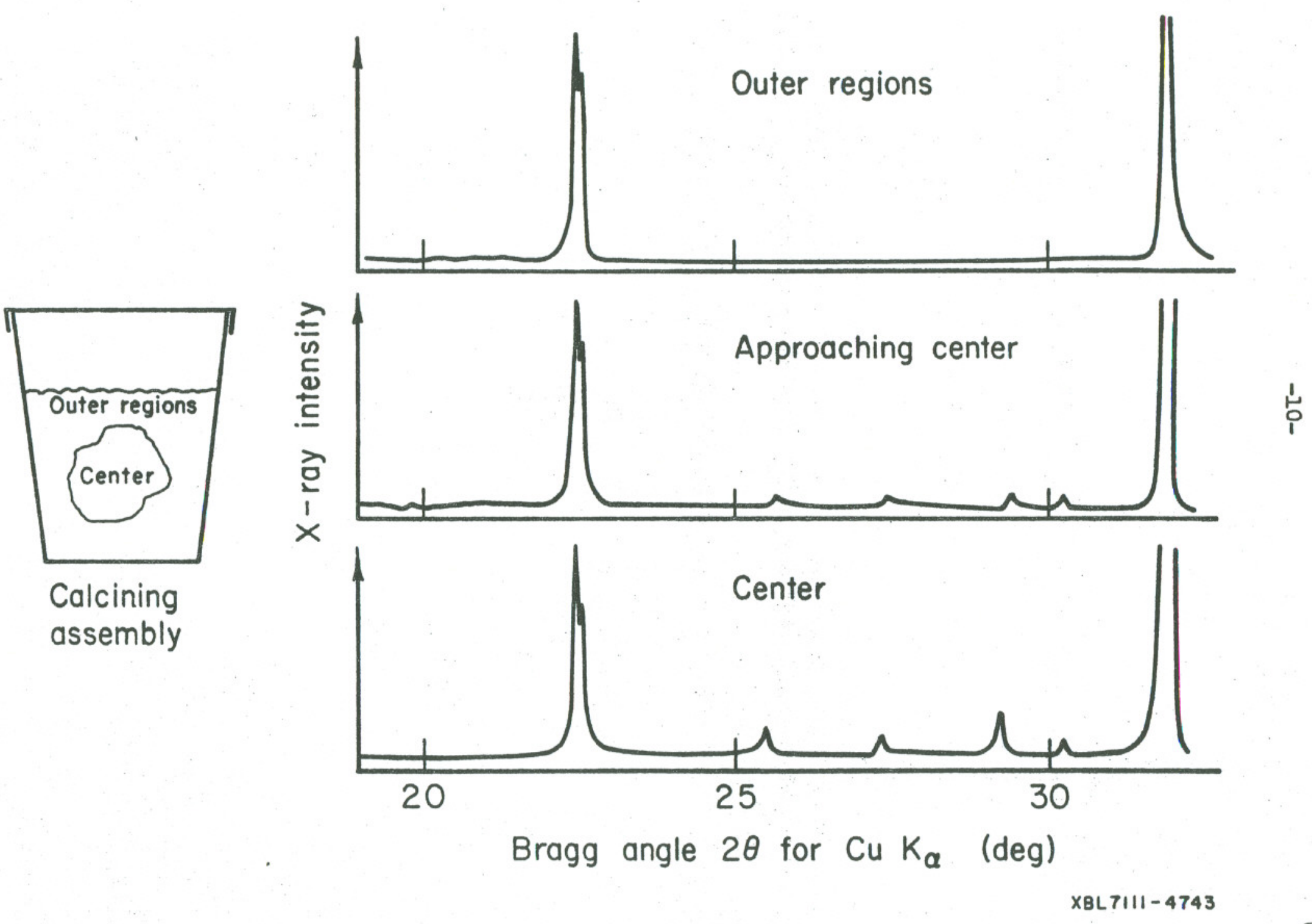

Fig. 4. X-ray patterns showing concentration gradient of second phase, $(\mathrm{NaK}) \mathrm{Nb}_{8} \mathrm{O}_{21}$, in $\mathrm{NKN}$ in $\mathrm{calcining}$ compact. 
approached with the pressed pellet showing an even greater gradient. The $\mathrm{X}$-ray patterns are included in the figure to show this gradient. To eliminate this second phase, mixtures with varying amounts (up to 2 mole $\%$ ) of excess nitrates were calcined. The second phase was still present. Because the interior of the calcining compact contained the second phase, calcining in thin sections to allow for gas escape was tried, assuming the gas reaction product inhibited the reaction. In order to obtain more material per firing, plates of fused silica were used. The plates were six inches square and were used to support platinum foil on which thin coatings of the mixed oxides were placed forming a shallow bed. The results of this method of calcining are shown in Fig. 5. Again, as the depth of the material increased, the second phase concentration increased. Also, the single phase material was crusty and hard and appeared to have formed from a melt, while the two-phase sections were unagglomerated and easily crushed.

To better understand the calcining reactions, two thermogravimetric analyses were run on the dry mixed materials at heating rates of $21 / 2^{\circ} \mathrm{C}$ and $12^{\circ} \mathrm{C}$ per minute. The results showed that only one major loss of weight occurred which coincided with the decomposition of the nitrates and was quantitatively predictable according to Eq. (2). The data also showed that at the slow heating rate, the decomposition was complete at about $700^{\circ} \mathrm{C}$, compared to $830^{\circ} \mathrm{C}$ for the faster heating rate.

Differential thermal analyses of the mixed powders were also done. The results are shown in Fig. 6. It is evident from the data that the degree of packing of the powder before calcining has a marked effect on the reaction. At $690^{\circ} \mathrm{C}$ an endothermic and exothermic reaction take 


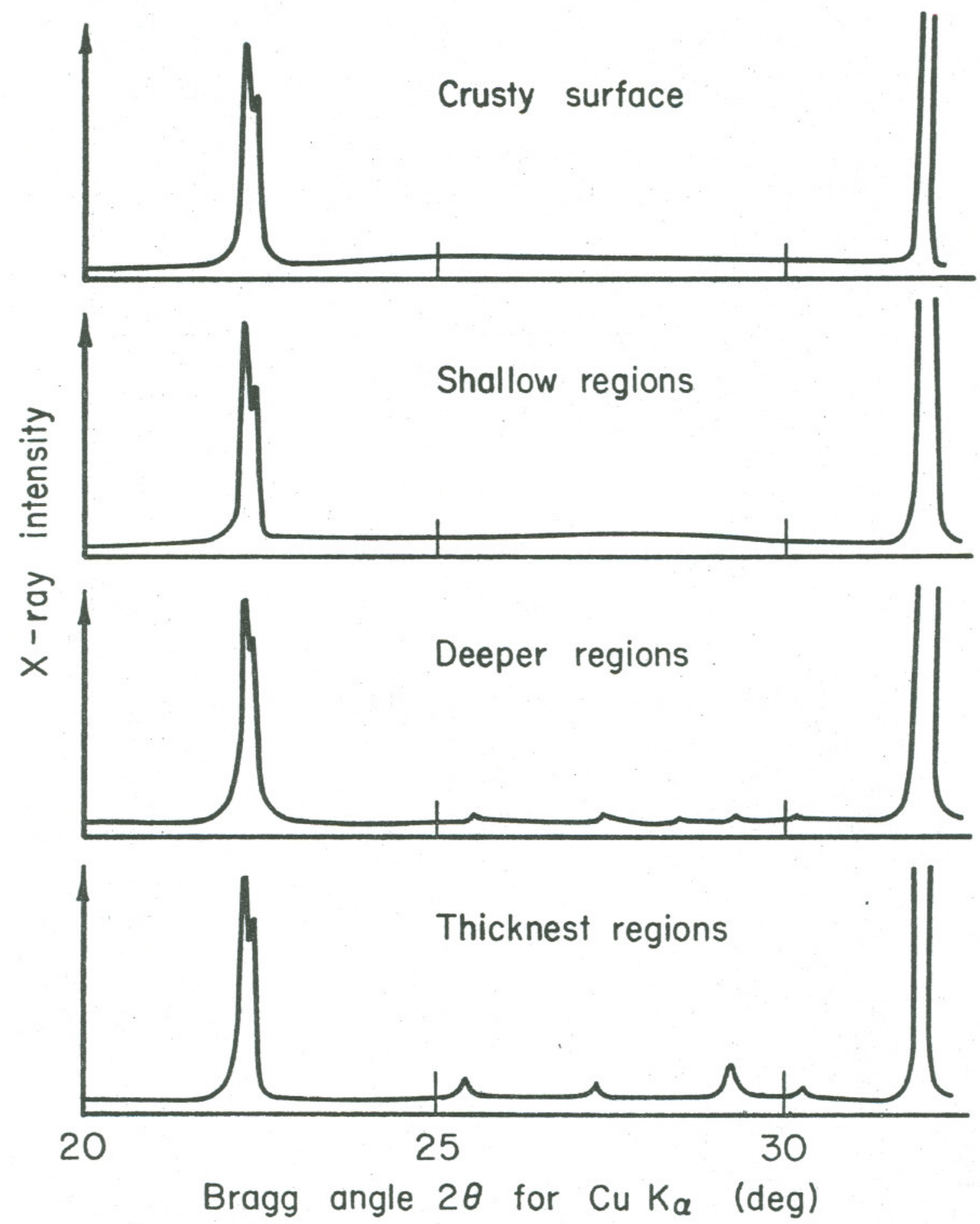

$X B L 7 I I I-4744$

Fig. 5. X-ray patterns showing concentration gradient of second phase, $(\mathrm{NaK}) \mathrm{Nb}_{8} \mathrm{O}_{21}$ in $\mathrm{NKN}$ for tray firing assembly. 

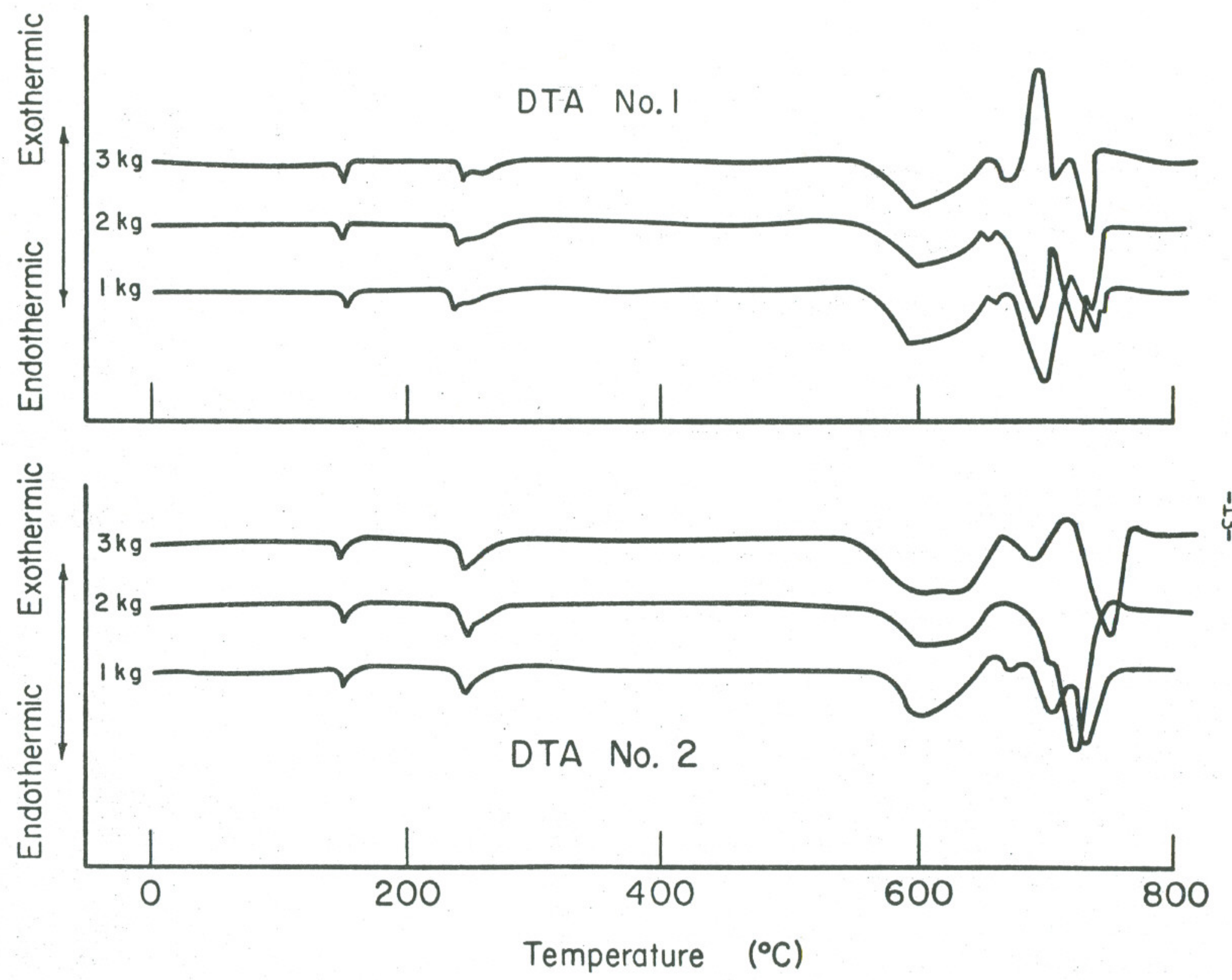

XBL7III- 4742

Fig. 6. Differential thermal analysis curves for reactions during calcination of mixed oxides with compacting pressure at the left for each sample. 
place. Loose packing favors the endothermic reaction while tight packing shows an exothermic reaction.

An additional experiment done was a gradient firing experiment. ${ }^{12}$ The gradient firing experiment was done in a furnace designed to keep the temperature gradient between the center and exterior of the sample constant. For example, for an endothermic reaction, the heating rate is slowed down until the reaction is completed. The gradient firing data is shown in Fig. 7. When the decision to study the $\mathrm{NaNbO}_{3}$ system was made, the calcining experiments, the DTA studies, and the thermogravimetric analyses had already been done on the NKN materials. The gradient firing experiment served to show that the reactions occurring in the $\mathrm{NaNbO}_{3}$ and the NKN systems are analgous.

\section{Sintering Studies}

Each of the different batches of calcined single phase NKN, doped and undoped, was ground for 50 hours in a polyethylene container with teflon media to reduce particle size. This was followed by air firing at $450^{\circ} \mathrm{C}$ for 20 hours. Next the powder was passed through a 325 mesh screen and average particle size of 4.2 microns was determined using the "Fisher Sub Sieve Sizer."

The powder agglomerated easily so that no binding agent was needed in cold pressing. One-half inch diameter by one-eighth inch high pellets were cold pressed at 40,000 psi. Density determinations were made by two methods, mass volume measurements and mercury immersion. Green densities ranged from $63 \%$ to $72 \%$ of theoretical density.

The pellets were sintered in a covered platinum crucible with an oxygen pressure of one atmosphere. They were surrounded by packing 


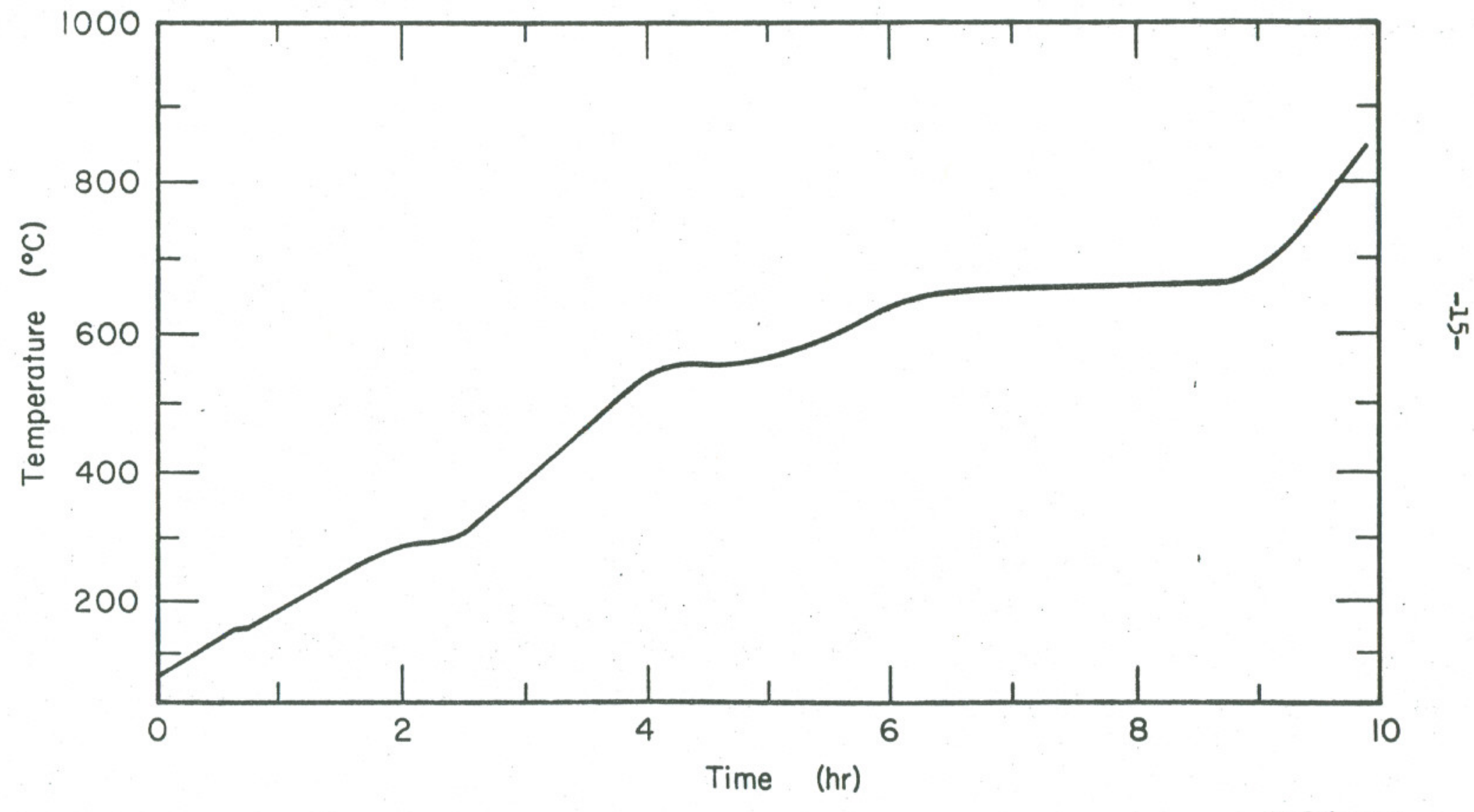

XBL7III-474I

Fig. 7. Thermal gradient analysis of mixed oxides during calcining to form $\mathrm{NaNbO}_{3}$. 
powder containing 3 mole \% excess $\mathrm{Nb}_{2} \mathrm{O}_{5}$ to keep the system on the high niobium side of the phase diagram.

Sintering was done in a kanthal wound furnace that was designed for loading and quenching from the hot zone in less than 10 seconds. Before insertion into the hot zone, the loaded crucible was evacuated in a dessicator and then filled with oxygen gas. After each insertion into the hot zone, 30 minutes were allowed for the specimens to reach the sintering temperature.

Fracture surfaces of pellets coated with a thin platinum-palladium layer to prevent charging were observed with the scanning electron microscope to study their microstructure.

Also, one sample of $44>x>37$ micron sized NKN, undoped and in a hand pressed pellet was sintered in the hot-stage of the microscope. Photos were taken at $100^{\circ}$ to $150^{\circ}$ intervals up to $1100^{\circ} \mathrm{C}$. $\mathrm{X}$-ray diffraction patterns were determined for the sintered pellets showing that they were still single phase NKN. 


\section{RESULTS AND DISCUSSION}

\section{A. Calcining Reactions}

The X-ray diffraction pattern for pure single phase NKN as indexed by Stannek ${ }^{4}$ is shown in Fig. 8. Added to the pattern, however, are two broad peaks at Bragg angles of about 11.2 and 15.8. These peaks were calculated to be caused by diffraction from the multiple cell planes $\{001 / 2\}$ and $\{1 / 21 / 20\}$ respectively. This seems reasonable because both end members of the solid solution, $\mathrm{NaNbO}_{3}$ and $\mathrm{KNbO}_{3}$ exhibit this multiple cell diffraction phenomenon as shown by E. A. Wood. ${ }^{13}$

Concerning the reactions occurring during the calcining of NKN, it is less complicated to study the $\mathrm{NaNbO}_{3}$ system for phase identification. Pure $\mathrm{NaNbO}_{3}$ is shown in Fig. 9, along with a typical calcined specimen broken down into various regions. Note the increasing concentration of the second phase and how similar the gradient is to that of NKN in Fig. 4.

In Fig. 10 the X-ray diffraction pattern of $\mathrm{NaNbO}_{3}$ with a high concentration of the second phase is shown. Also shown is the pattern for $\mathrm{Na}_{2} \mathrm{Nb}_{8} \mathrm{O}_{21}$. It is evident that $\mathrm{Na}_{2} \mathrm{Nb}_{8} \mathrm{O}_{21}$ is the second phase present. Based on the $X$-ray patterns taken at various temperatures and the DTA patterns, a possible reaction series has been postulated.

The following is the reaction series. At about $150^{\circ} \mathrm{C}$ the moisture in the powder evaporates and the system remains unchanged until $240^{\circ} \mathrm{C}$ when the nitrate compounds melt. As $600^{\circ} \mathrm{C}$ is approached, the nitrates and $\mathrm{Nb}_{2} \mathrm{O}_{5}$ start reacting endothermically to form $\mathrm{Na}_{2} \mathrm{Nb}_{8} \mathrm{O}_{2} 1$ for the $\mathrm{NaNO}_{3}-\mathrm{Nb}_{2} \mathrm{O}_{5}$ system and $(\mathrm{NaK}) \mathrm{Nb}_{8} \mathrm{O}_{2}$ for the ternary system. The temperature of this reaction is lower in the gradient run because only $\mathrm{NaNO}_{3}$ is present but the order and magnitude of the peaks are the same as the 

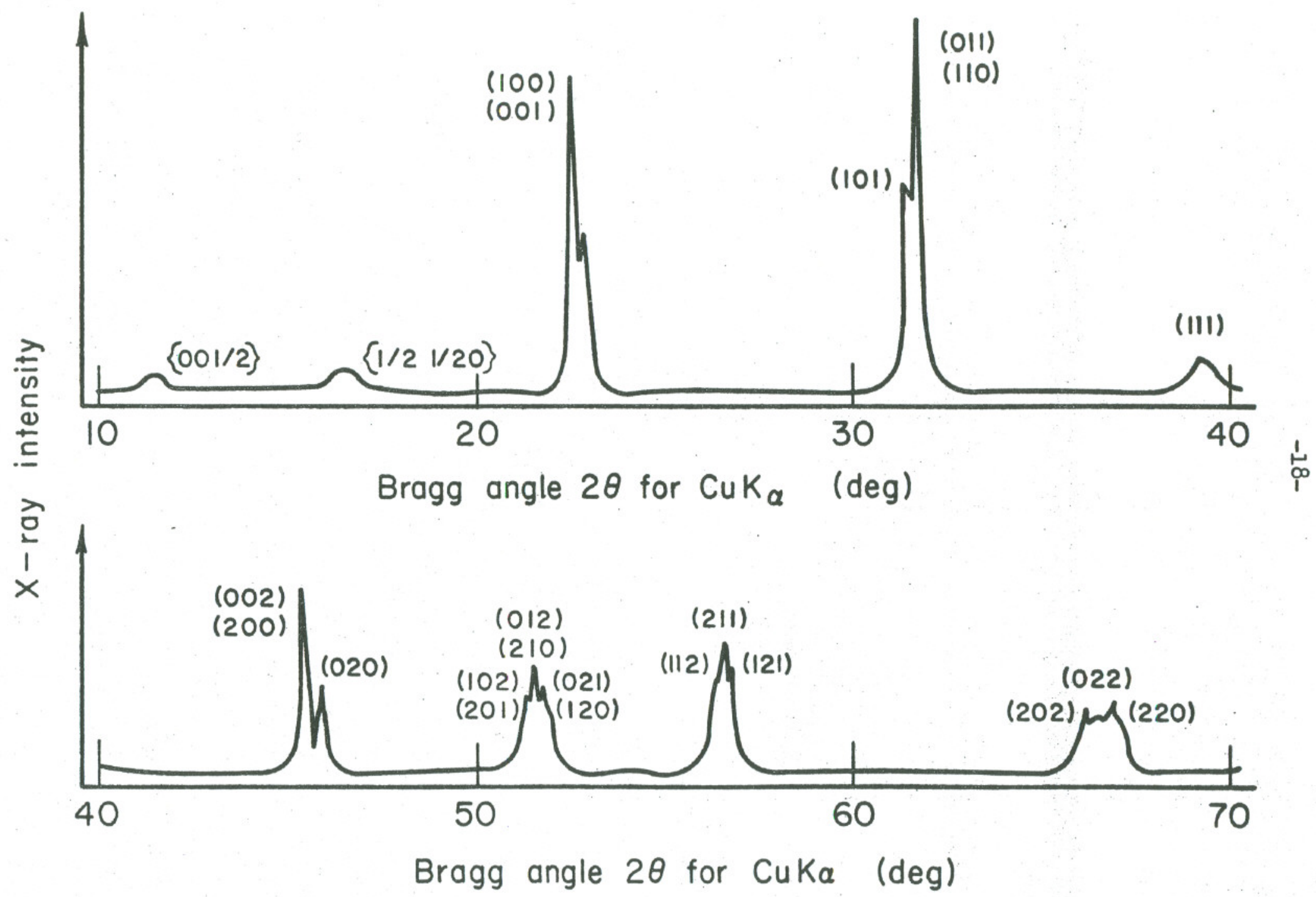

XBLTIII-4738

Fig. 8. Indexed X-ray pattern for $\left(\mathrm{Na}_{0} \cdot{ }_{5} \mathrm{~K}_{0} \cdot 5\right) \mathrm{NbO}_{3}$. 

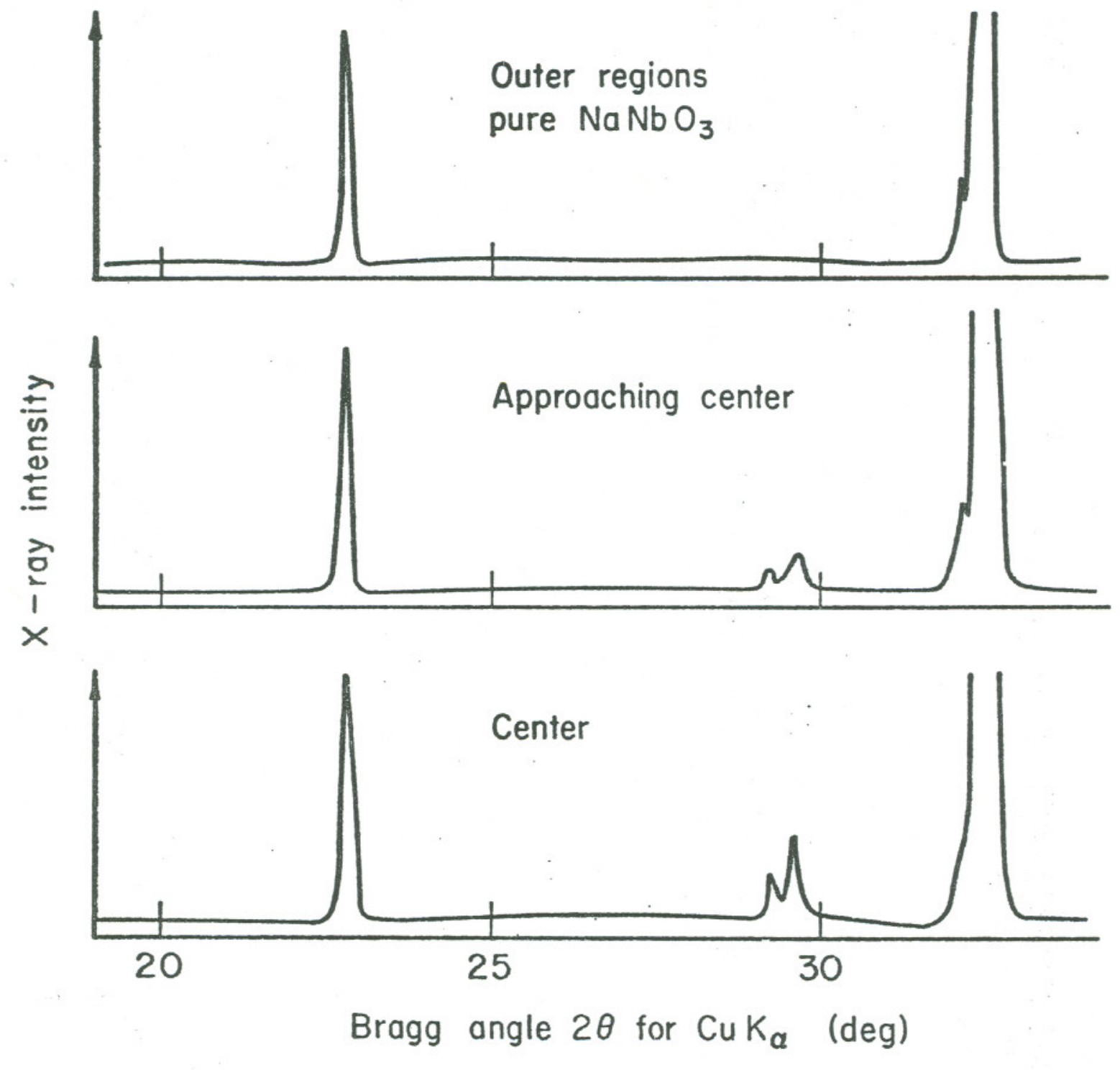

$X B L 7111-4739$

Fig. 9. X-ray patterns showinf concentration gradient of second phase, $\mathrm{Ia}_{2} \mathrm{Nb}_{8} \mathrm{O}_{21}$, in $\mathrm{NaNbO}_{3}$ for a calcined compact. 


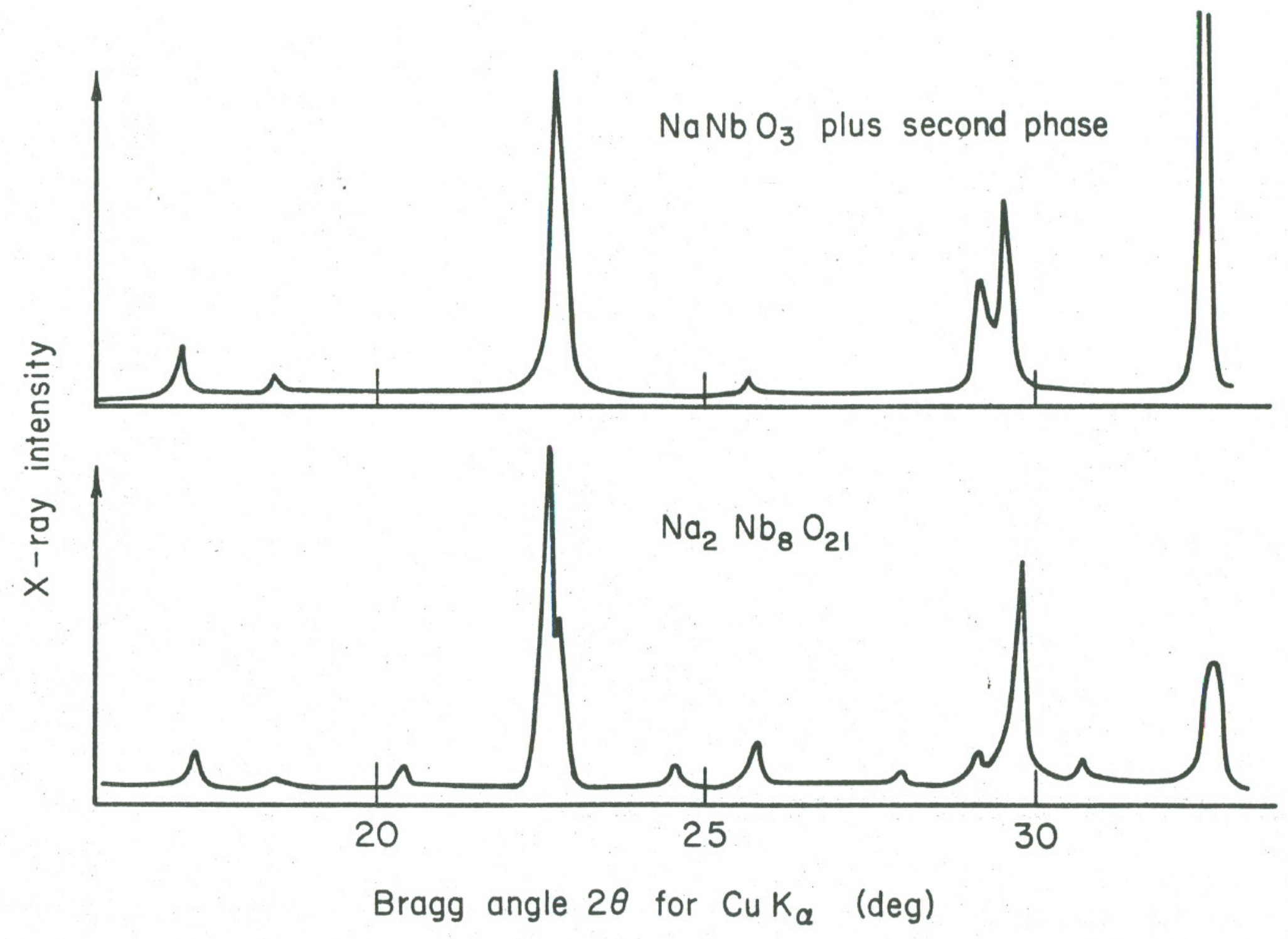

Figure 10. X-ray patterns for $\mathrm{NaNbO}_{3}$ (containing second phase) and $\mathrm{Na}_{2} \mathrm{Nb}_{8} \mathrm{O}_{21}$. 
DTA analyses for NKN material. From X-ray patterns shown in Fig. 1l, the $(\mathrm{NaK}) \mathrm{Nb}_{8} \mathrm{O}_{21}$ is forming at the expense of $\mathrm{Nb}_{2} \mathrm{O}_{5}$ and the nitrates. But loss of weight doesn't occur in the NKN system until a slightly higher temperature, $615^{\circ} \mathrm{C}$. At some temperature above $600^{\circ} \mathrm{C}$ the first NKI peaks appear and as temperature increases to $700^{\circ} \mathrm{C}$, the $\mathrm{NKN}$ phase continued to grow at the expense of the $(\mathrm{NaK}) \mathrm{Nb}_{8} \mathrm{O}_{21}$ phase. If the reaction goes to completion then all the $(\mathrm{NaK}) \mathrm{Nb}_{8} \mathrm{O}_{21}$ should convert to $\mathrm{NKN}$.

The reason for the concentration gradient of $(\mathrm{NaK}) \mathrm{Nb}_{8} \mathrm{O}_{21}$ appearing in this system is a diffusion problem and is shown in Fig. 12. Initially, at just under $600^{\circ} \mathrm{C}$ the pellet or powder compact of raw materials has formed a solid solution of $(\mathrm{NaK}) \mathrm{Nb}_{8} \mathrm{O}_{21}$ and $(\mathrm{NaK}) \mathrm{O}$, or $\left(\mathrm{NaK}^{2} \mathrm{NO}_{3}\right.$ liquid. As the temperature increases, the nitrate gases leave the system (accounting for the weight loss). Also, (NaK)O begins to evaporate from the surface resulting in the concentration gradient shown in Fig. 12A. The temperature for the formation of $\mathrm{NKN}$ is reached at the surface and the $(\mathrm{NaK}) 0$ reacts with the $(\mathrm{NaK}) \mathrm{Nb}_{8} \mathrm{O}_{21}$ at the surface to form NKN. This reaction acts like a sink for $(\mathrm{NaK}) \mathrm{O}$ and the system sees the same (NaK)O concentration gradient as in Part A but with a smaller diameter pellet and less ( $\mathrm{NaK}$ ) O as shown in Part $\mathrm{B}$. As the reaction temperature moves inward, the above process continues, Part C. The last stage is the point at which the entire pellet has reached the reaction temperature and the remaining ( $\mathrm{NaK}) 0$ has reacted to form $\mathrm{NKN}$. If there is a deficiency of $(\mathrm{NaK}) \mathrm{O}$ in the system due to vaporization, then the presence of the second phase in the center after calcining is explained. The solution is to add a larger quantity of excess $\mathrm{NaNO}_{3}$ and $\mathrm{KNO}_{3}$ before calcining. 
$-22-$
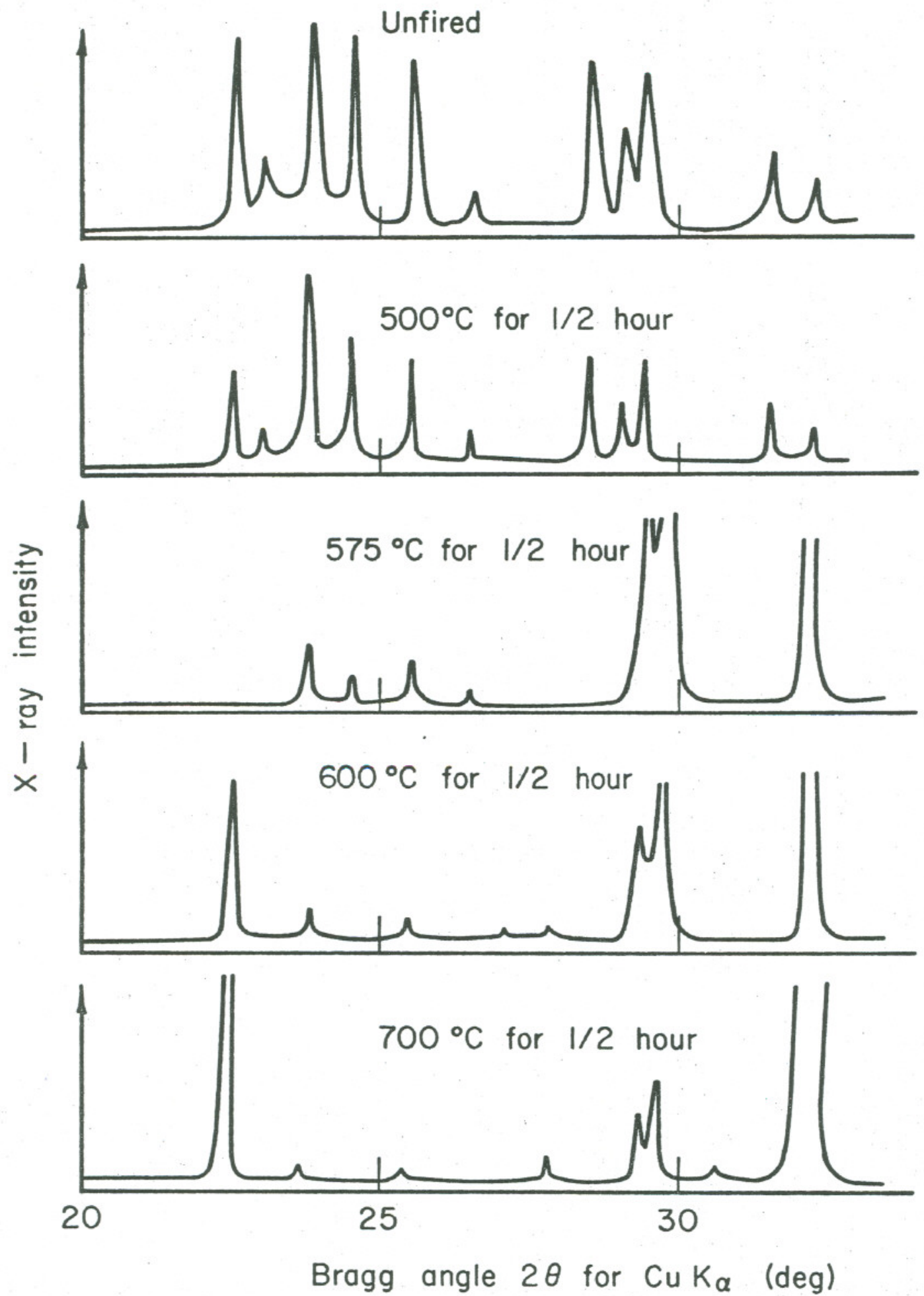

$X B L 7 I I I-4736$

Fig. 11. Calcining history of $N K N$ using X-ray diffraction patterns. 


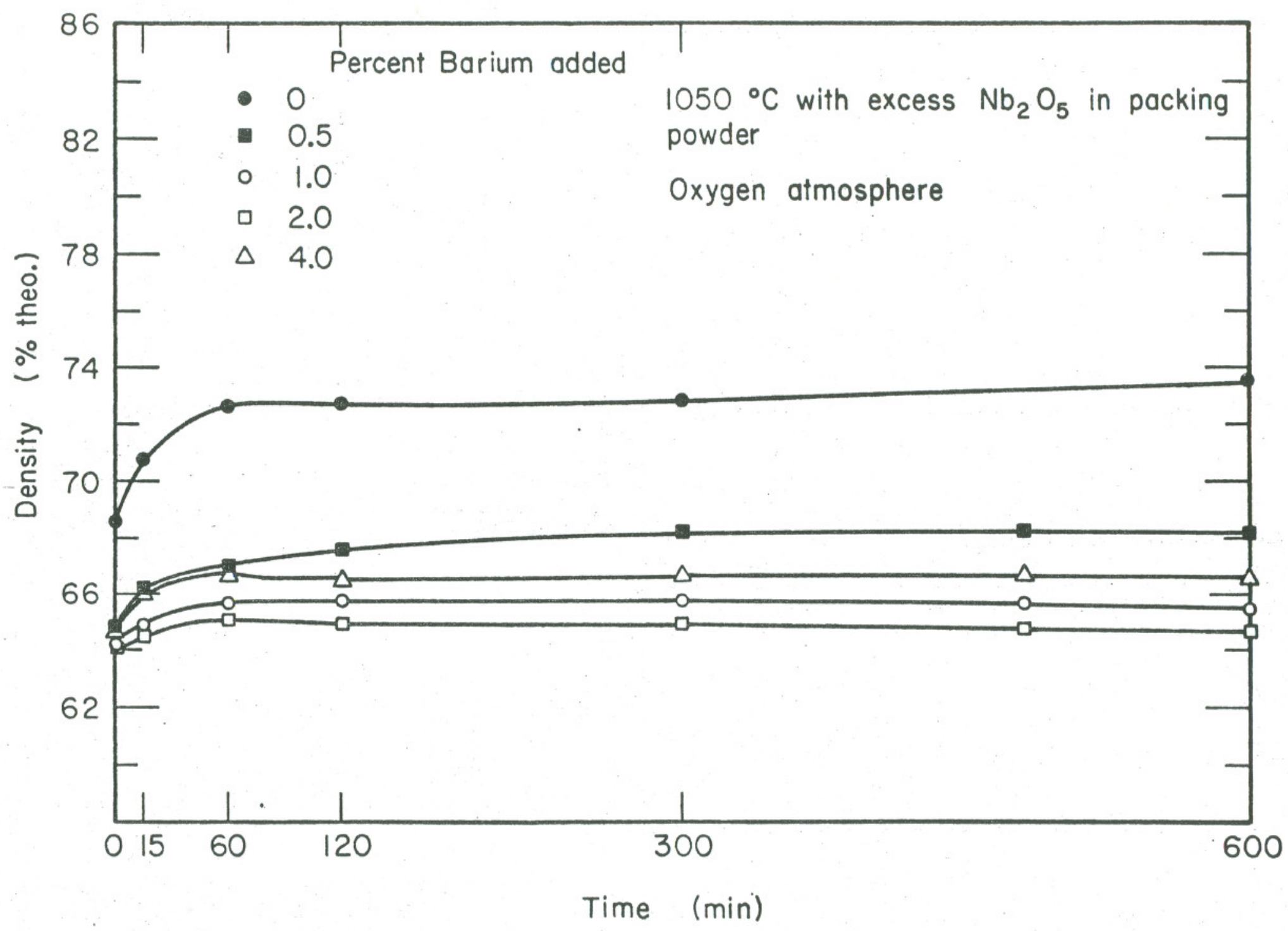

Fig. 13. Relative density of $\mathrm{NKN}$ pellets versus sintering time at $1050^{\circ} \mathrm{C}$. 


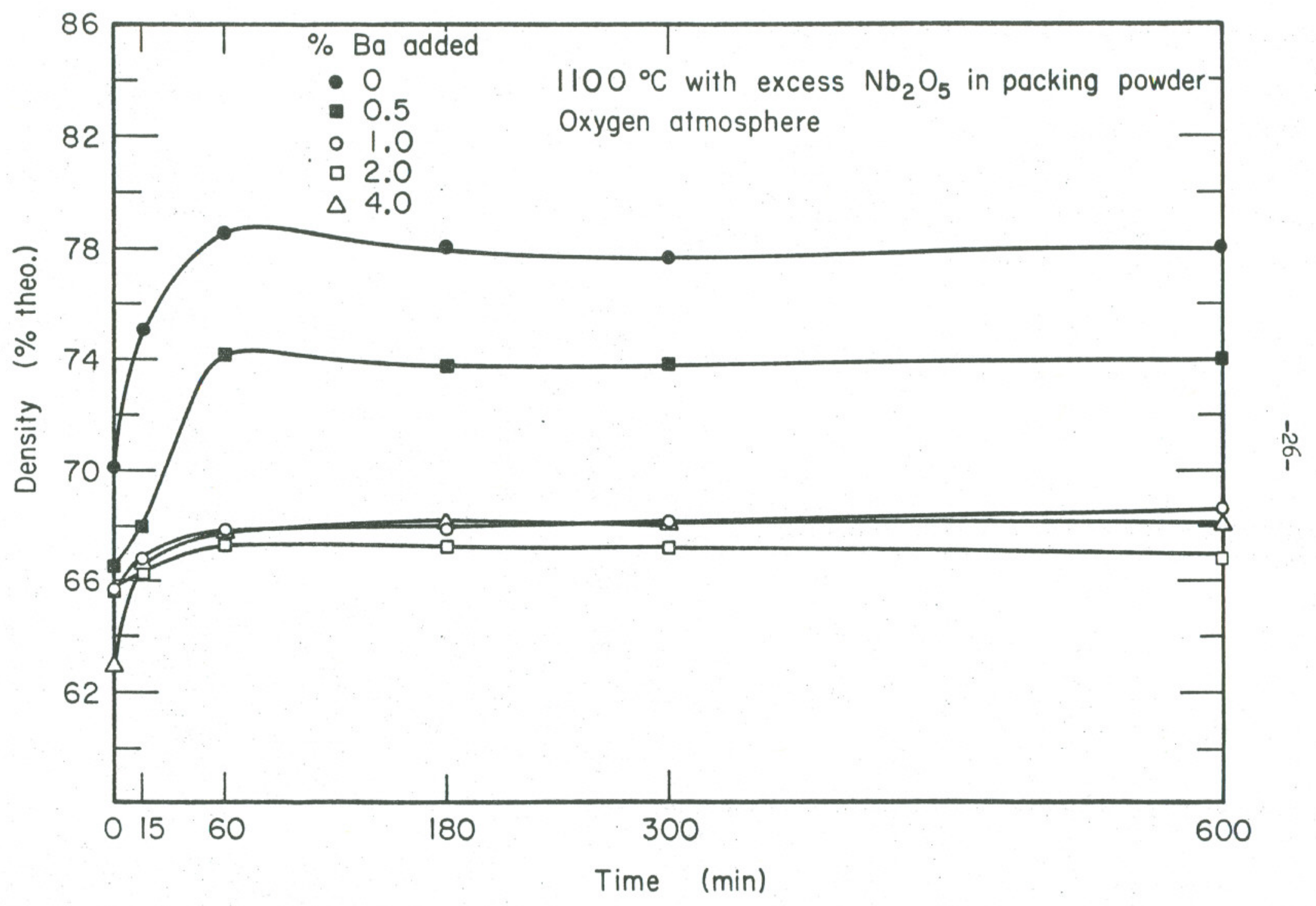

XBL $7111-4747$

Fig. 14. Relative density of $\mathrm{NKN}$ pellets versus sintering time at $1100^{\circ} \mathrm{C}$. 


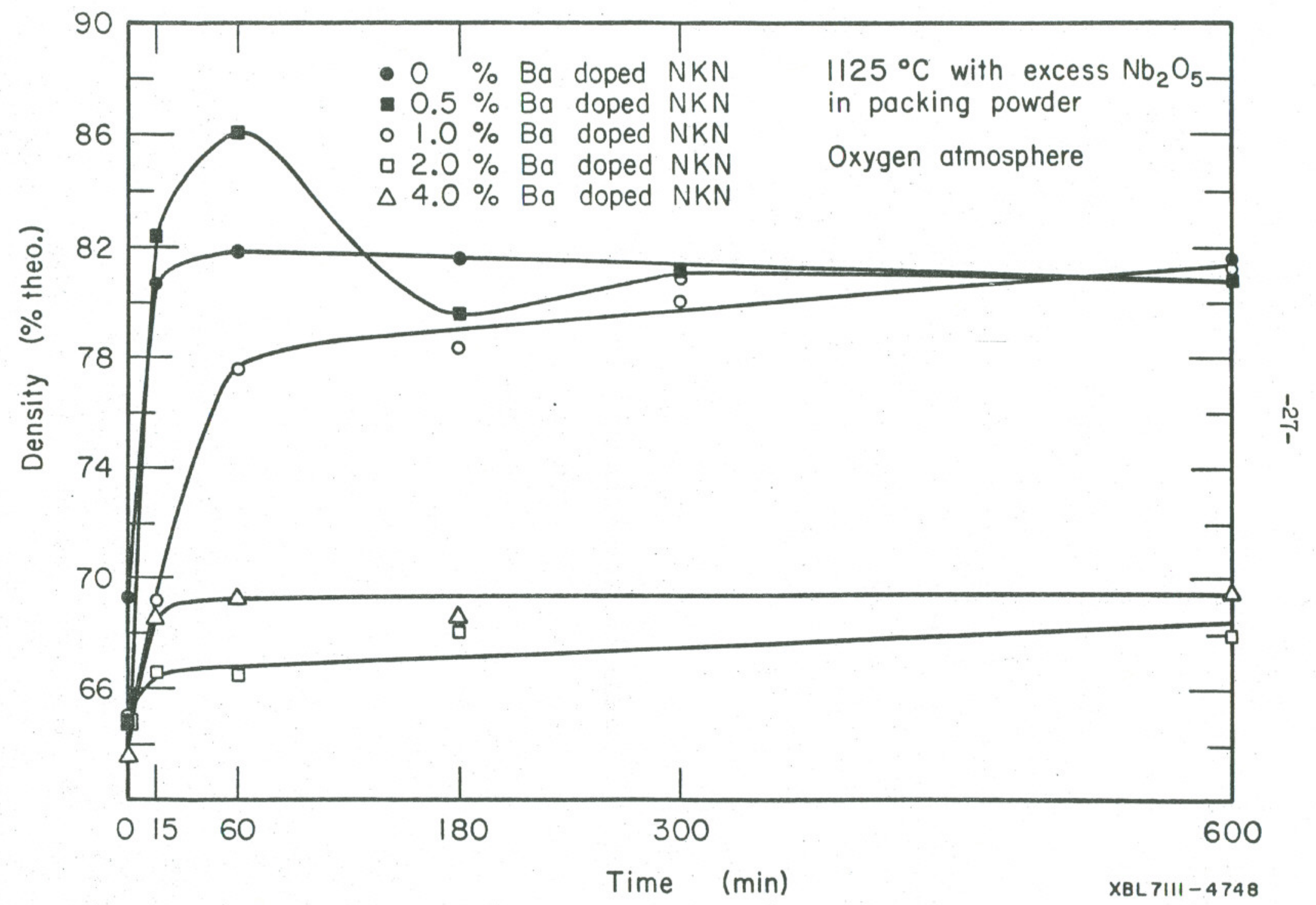

Fig. 15. Relative density of NKN pellets versus sintering time at $1125^{\circ} \mathrm{C}$. 


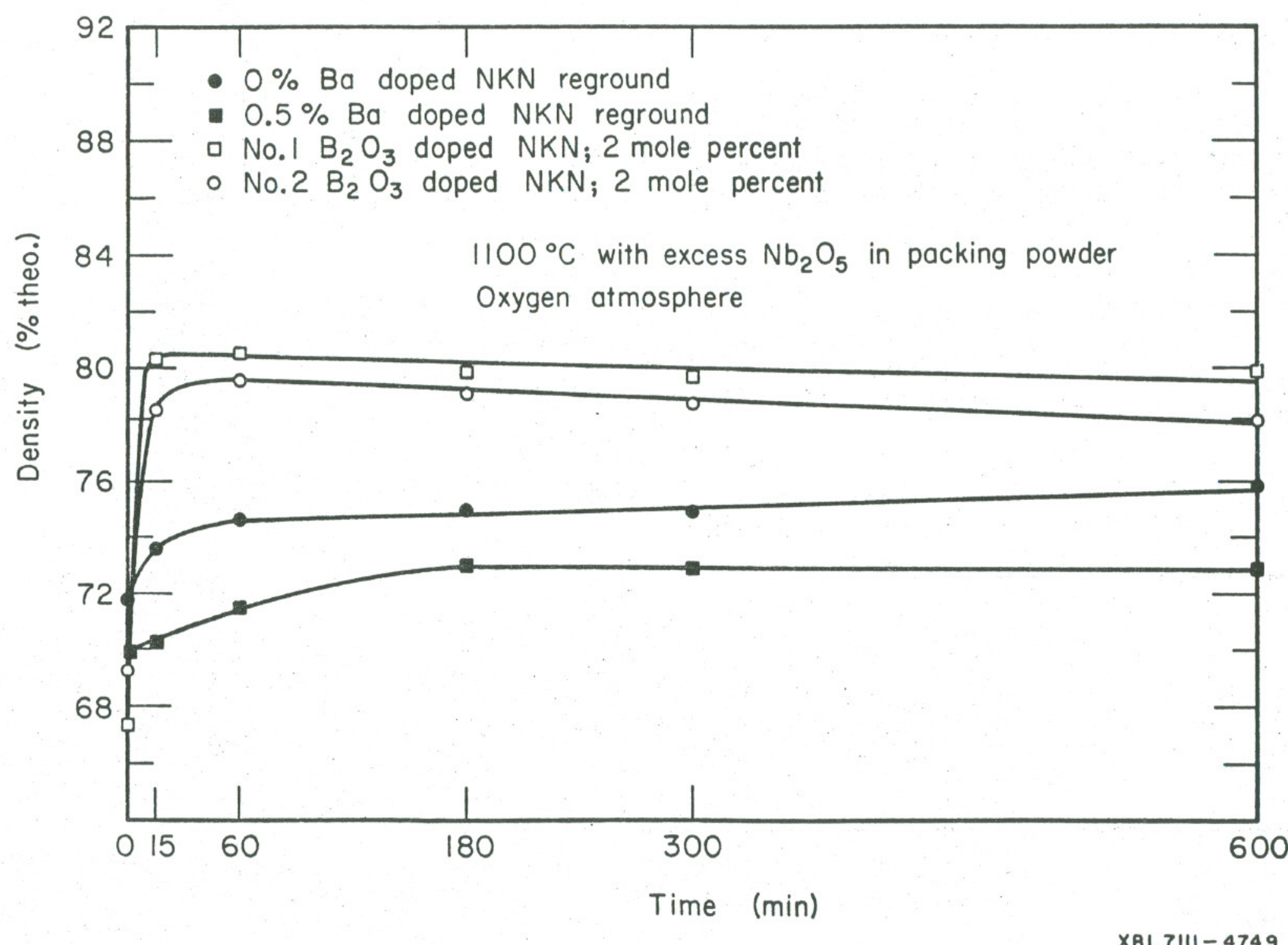

Fig. 16. Relative density of NKN pellets versus sintering time at $1100^{\circ} \mathrm{C}$. 
appreciably the densification of PZT ferroelectrics. Undetected impurities in NKN could account for the liquid phase.

$\mathrm{B}_{2} \mathrm{O}_{3}$ was added to create a liquid phase. Its sintering curves agree with the postulated theory, rapid initial densification only.

Stannek ${ }^{4}$ said that the cubic grains of NKN had a very low surface energy and that this would lead to a small driving force for sintering. This is why densification stops after the rearrangement stage.

Barium was added as a dopant to reduce grain growth. Microstructures of doped and undoped $\mathrm{NKN}$ as observed with the scanning electron microscope are shown in Figs. 17, 18, 19, 20, and 21. Figure 17 shows a series of pictures of undoped NKN sintered in the hot stage. These pictures show the disappearance of the smaller grains and some rearrangement. Figures 18, 19, and 20 show the effect of $\mathrm{Ba}^{+2}$ additions to NKN at different sintering temperatures. At each temperature the effect of increasing $\mathrm{Ba}^{+2}$ additions on reducing grain growth is evident. However, as temperature is increased, the effectiveness of $\mathrm{Ba}^{+2}$ as a grain growth inhibitor decreases. The effect of $\mathrm{B}_{2} \mathrm{O}_{3}$ on microstructure is shown in Fig. 21. It is similar to the undoped NKN in that the liquid phase appears to have been formed.

The amount of liquid phase appears to decrease with increasing $\mathrm{Ba}^{+2}$ additions. From Kingery's relationship between rearrangement densification and volume fraction liquid, the $\mathrm{Ba}^{+2}$ is postulated to prevent formation of a liquid phase, i.e., rearrangement. 

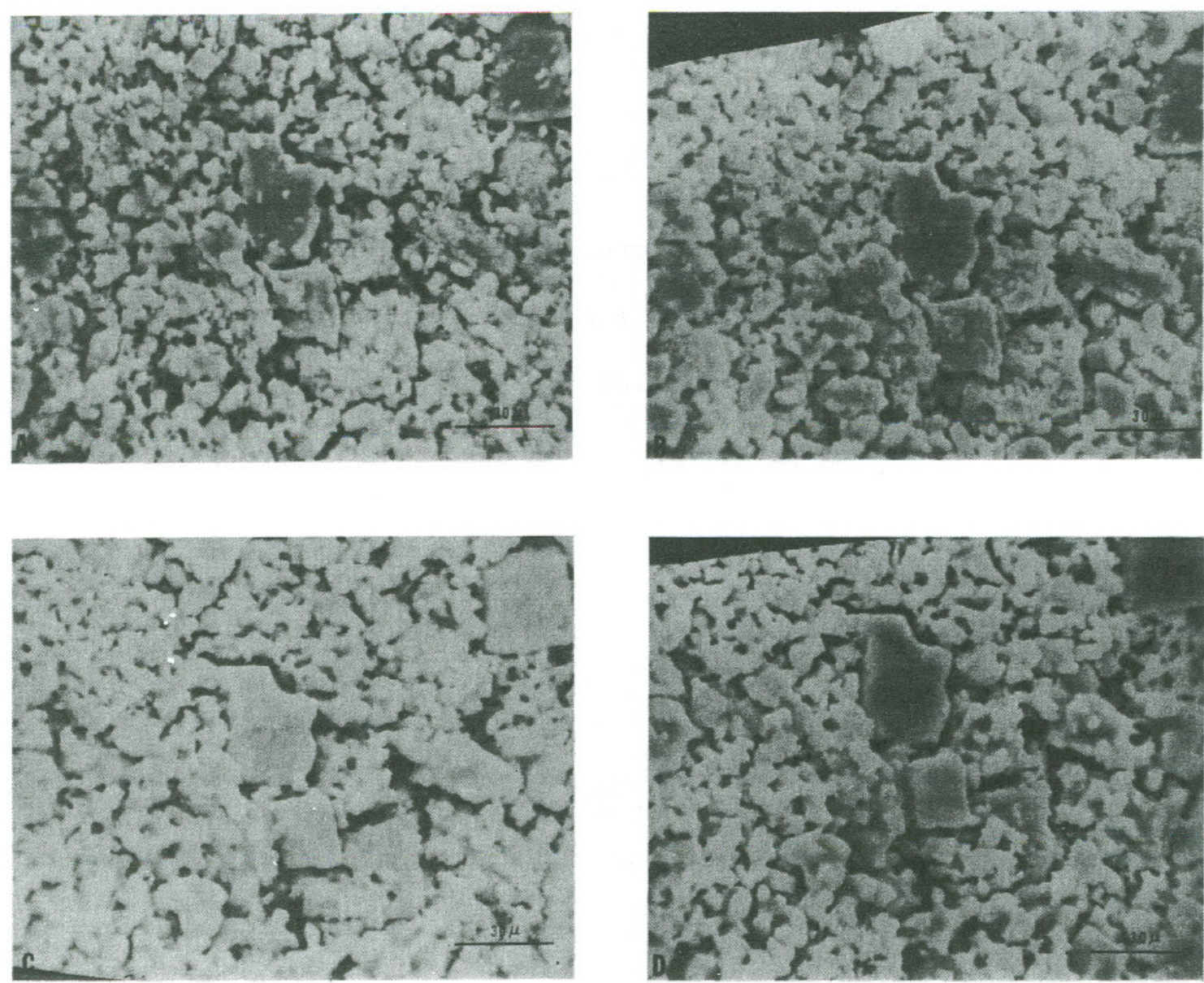

XBB 71115600

Fig. 17. Scanning electron microscope pictures of NKIN in hot stage in vacuum.
A. $540^{\circ} \mathrm{C}$
B. $950^{\circ} \mathrm{C}$
C. $1050^{\circ} \mathrm{C}$
D. $1100^{\circ} \mathrm{C}$ 

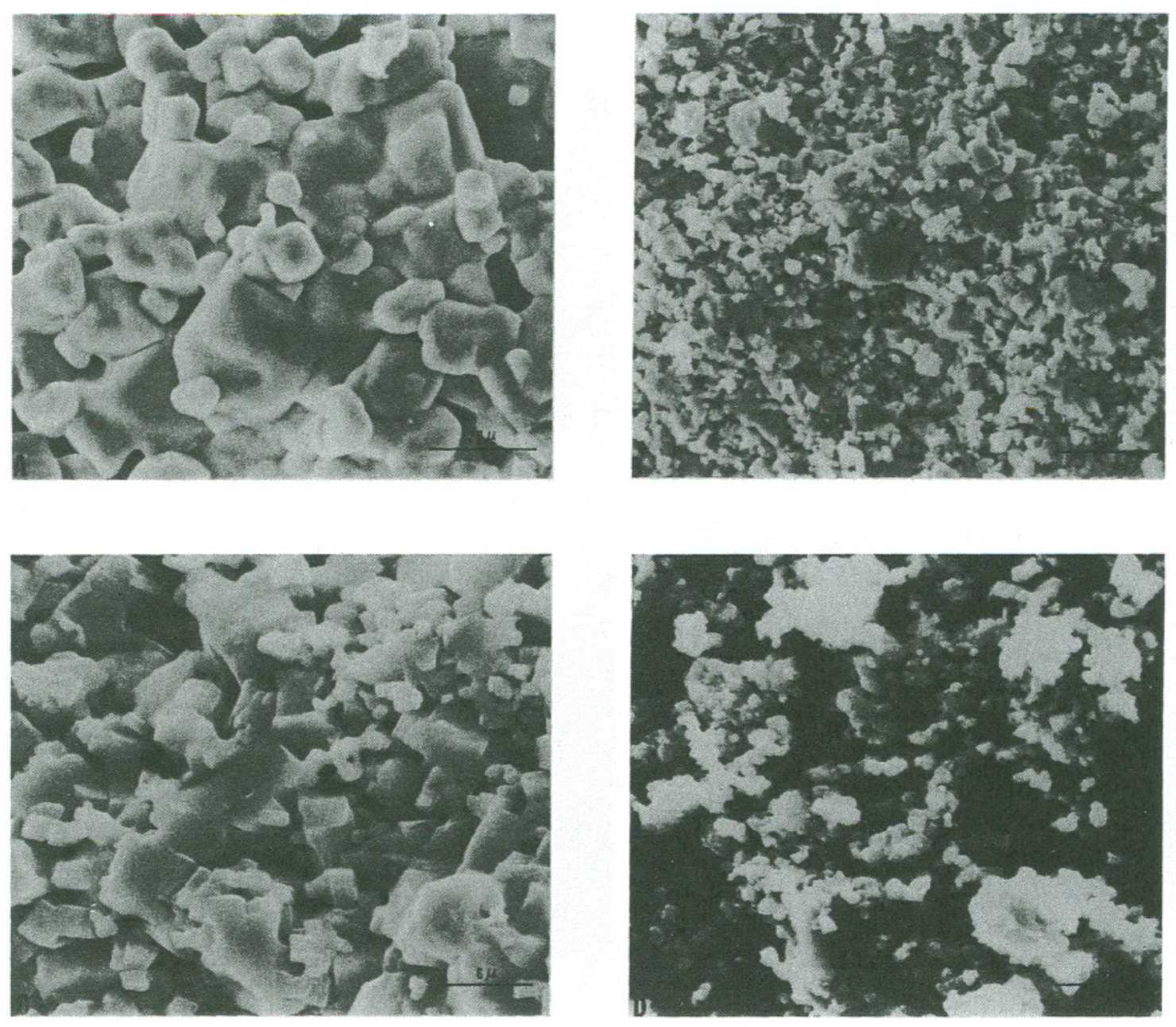

XBB 71115601

Fig. 18. Scanning electron microscope pictures of fracture surfaces of NKN pellets sintered for 10 hours at $1050^{\circ} \mathrm{C}$ in oxygen.
A. $\quad 0.0$ mole percent $\mathrm{Ba}^{+2}$
B. $0.5 "$ " " " "
$\begin{array}{llll}\text { C. } & 1.0 & \text { " } & \text { " } \\ \text { D. } & 4.0 & \text { " }\end{array}$ 

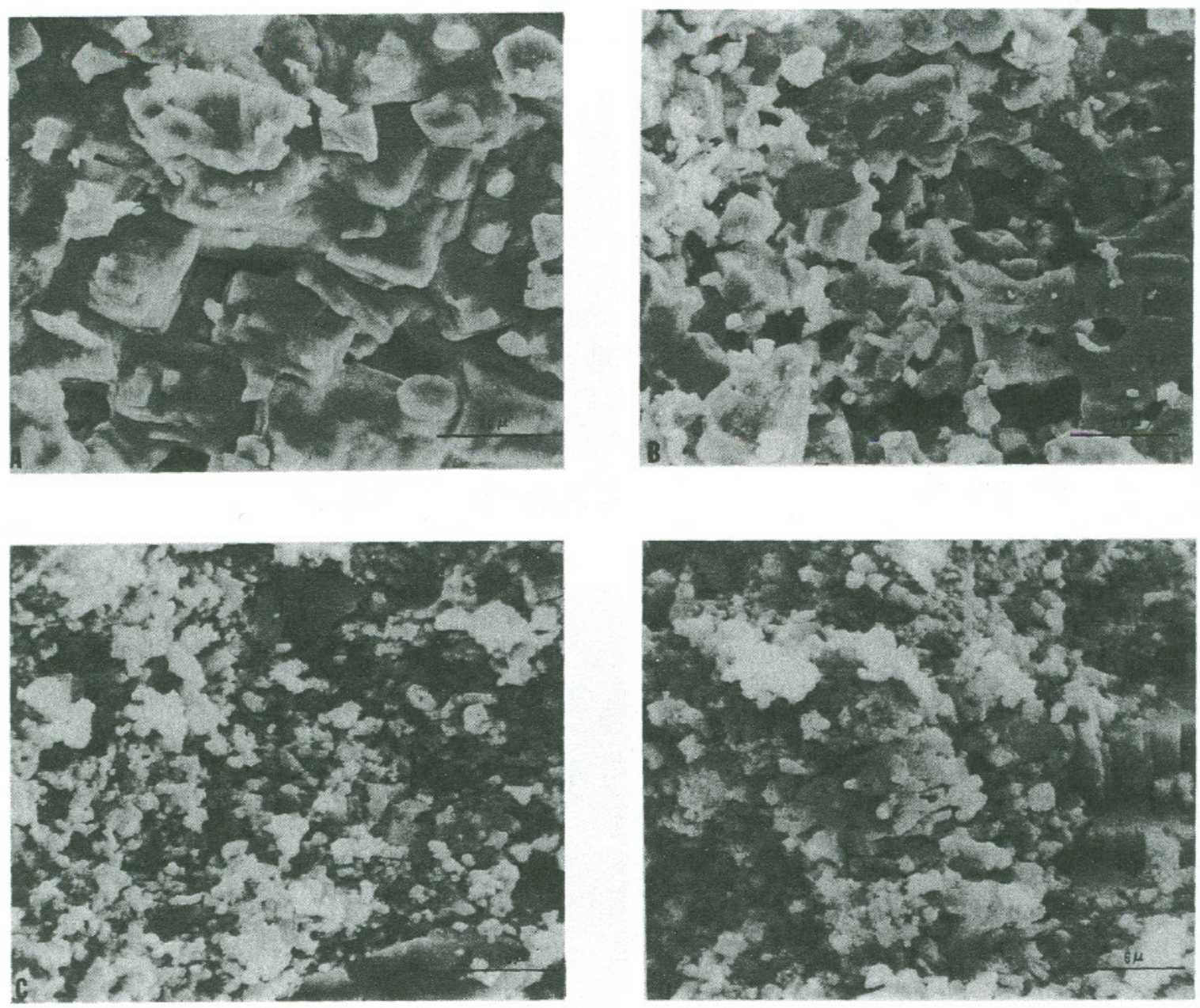

XBB 71115602

Fig. 19. Scanning electron microscope pictures of fracture surfaces of NKN pellets sintered for 10 hours at $1100^{\circ} \mathrm{C}$ in oxygen.
A. 0.0 mole percent $\mathrm{Ba}^{+2}$
B. $0.5 "$ " "
C. $1.0 "$ " "
D. $2.0 "$ " " 

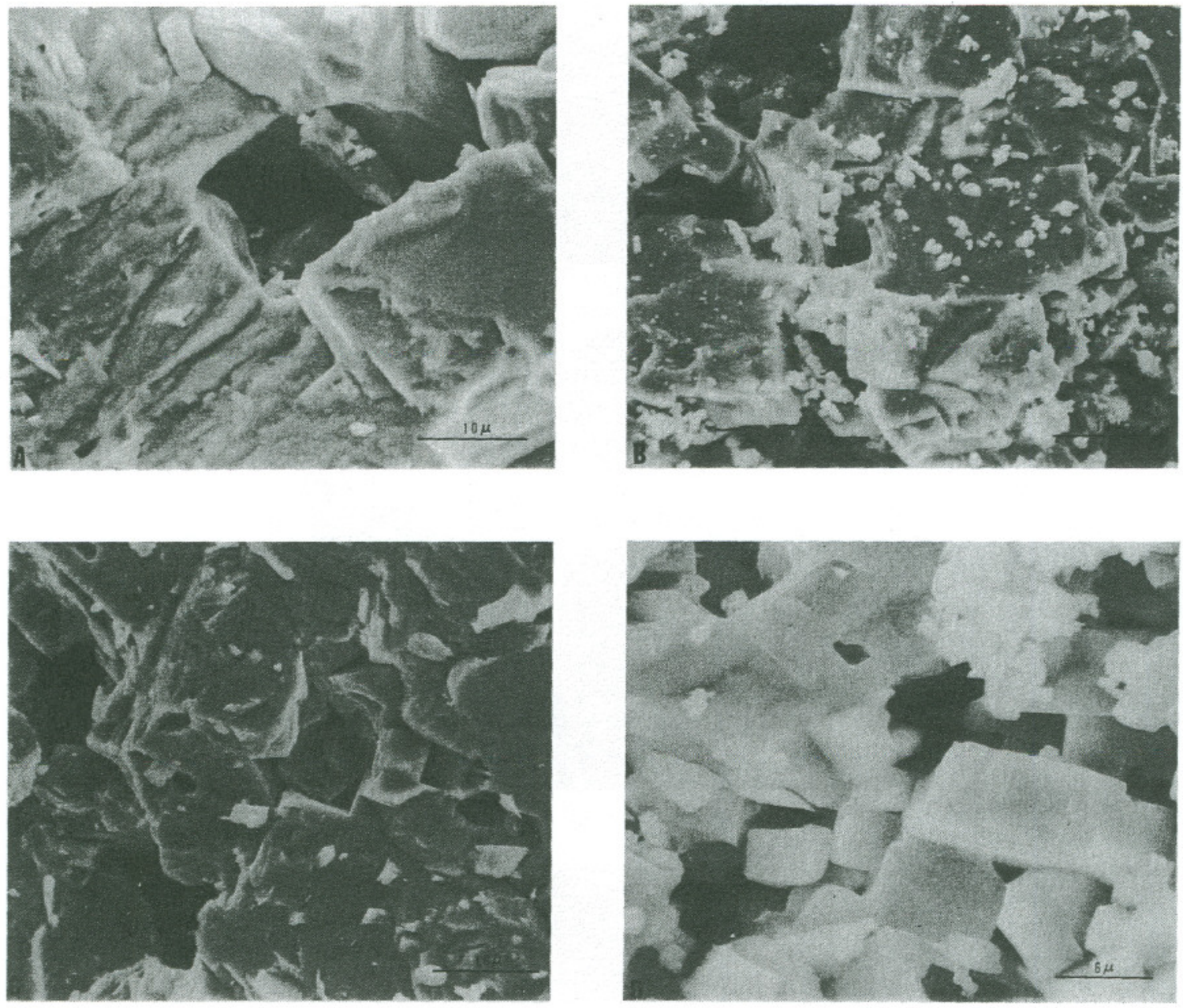

XBB 71115599

Fig. 20. Scanning electron microscope pictures of fracture surfaces of NKN pellets sintered for 10 hours at $1125^{\circ} \mathrm{C}$ in oxygen.
A. 0.0 mole percent $\mathrm{Ba}^{+2}$
B. $0.5 "$ " "
C. $1.0 "$ " " " "
D. $2.0 "$ " " 

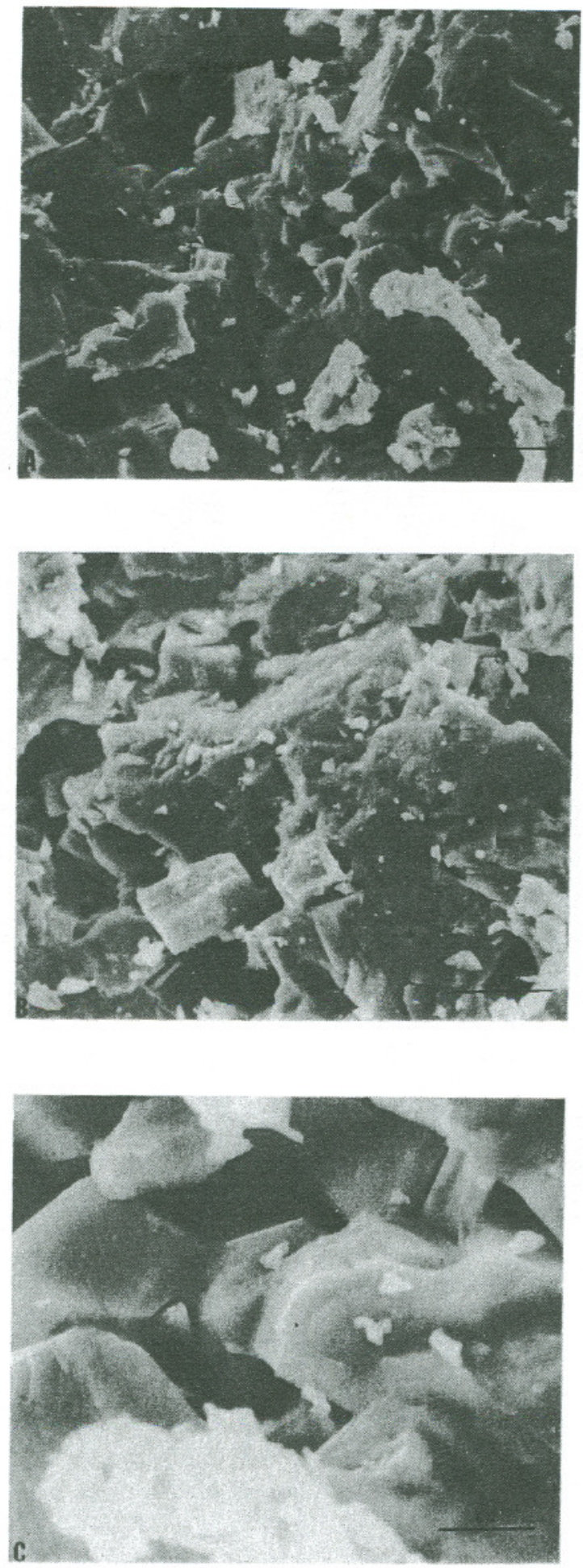

XBB 71115603

Fig. 2l. Scanning electron microscope pictures of fracture surfaces of NKN pellets sintered for 10 hours at $1100^{\circ} \mathrm{C}$ in oxygen. The pellets were doped with 2 mole percent $\mathrm{B}_{2} \mathrm{O}_{3}$. 
IV. CONCLUSION

The system $\left(\mathrm{Na}_{0} \cdot{ }_{5} \mathrm{~K}_{0} \cdot{ }_{5}\right) \mathrm{NbO}_{3}$ presents several interesting processing problems which are just beginning to be understood. The reactions taking place during calcining are: the formation of an intermediate compound, the reaction of this compound with sodium and potassium oxide to form NKN. Loss of sodium and potassium oxides due to vaporization during this reaction are significant enough to account for the presence of the intermediate compound in the calcined compact after calcining reactions have ceased.

NKN does not sinter per se. Densification occurs by particle rearrangement in the presence of a liquid phase. The driving force for sintering of $\mathrm{NKN}$ is so small that densification of the powder essentially stops after rearrangement although some de-densification is observed. Barium additions effectively reduce grain growth but do not increase sintering. In fact, large additions ( 2 and 4 mole $\%$ ) of $\mathrm{BaO}$ reduce the rearrangement densification. 


\section{ACKNOWLEDGMENTS}

The author wishes to thank Professor Richard M. Fulrath for his assistance and guidance in this work.

Thank you's are also awarded to Gautam Bandyopadhyay, Robert Holman, John Sherohman, and Craig Shumaker for many hours of interesting discussion.

I am also grateful to Kelly Radmilovic, Bill Bullis, Neal Houlding, and George Georgakapoulos for their assistance. And to Liz Chiu for being who she is.

Lastly, I would like to thank Local Board No. 70 for their continued interest in my affairs.

This work was done under the auspices of the United States Atomic Energy Commission.

"and the deep and dank tarn at my feet closed sullenly and silently over the fragments of the House of Usher." 


\section{REFERENCES}

1. J. E. May, Jr., "Ultrasonic Delay Lines," Bell Labs. Record, 35 [1] 212-6 (1956).

2. L. Egerton and Dolores M. Dillon, "Piezoelectric and Dielectric Properties of Ceramics in the System Potassium-Sodium Niobate," J. Am. Ceram. Soc., 42 [9] 438-42 (1959).

3. L. Egerton and C. A. Bieling, "Isostatically Hot-Pressed SodiumPotassium Niobate Transducer Material for Ultrasonic Devices," A. Ceram. Soc. Bull., 47 [12] 1151-6 (1968).

4. Wolfgang Stannek, "Characterization of Sintering Phenomena of $\left(\mathrm{Na}_{0} \cdot{ }_{5} \mathrm{~K}_{0} \cdot 5\right) \mathrm{NbO}_{3}, " \mathrm{M} . \mathrm{S}$. Thesis, Univ. of Calif., Berkeley, July 1970 (UCRL-19668) .

5. Adelheid Kofler, Monatsch. Chem., 86646 (1955).

6. M. W. Shafer and Rustum Roy, "Phase Equilibria in the System $\mathrm{Na}_{2} \mathrm{O}-\mathrm{Nb}_{2} \mathrm{O}_{5}, " \mathrm{~J}$. Am. Ceram. Soc., 42 [10] 482-5 (1959).

7. Arnold Reisman, Frederic Holtzberg and Ephraim Banks, "Reactions of the Group VB Pentoxides with Alkali Oxides and Carbonates. VII. Heterogeneous Equilibria in the System $\mathrm{Na}_{2} \mathrm{O}$ or $\mathrm{Na}_{2} \mathrm{CO}_{3}-\mathrm{Nb}_{2} \mathrm{O}_{5}$," J. Am. Chem. Soc., 80 [1] 37-42 (1958).

8. Arnold Reisman and E. Banks, "Reactions of the Group VB Pentoxides. III. Thermal, Density and $\mathrm{X}$-ray Studies of the Systems $\mathrm{KNbO}_{3}-$

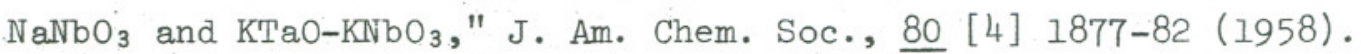

9. A. Reisman and F. Holtzberg, "Phase Equilibria in the System $\mathrm{K}_{2} \mathrm{CO}_{3}-\mathrm{Nb}_{2} \mathrm{O}_{5}$ by the Method of Differential Thermal Analysis," J. Am. Ceram. Soc., 77 2115 (1955). 
10. R. E. Jaeger and L. Egerton, "Hot-Pressing of Potassium-Sodium Niobates," J. Am. Ceram. Soc., 45 [5] 209-13 (1962).

11. D. J. Perduijn, R. R. P. Varekamp and H. C. Verjans, "Continuous Hot-pressing of Potassium-Sodium Niobate," Proc. Brit. Ceram. Soc., 18, 239-44 (Aug 1970).

12. Gautam Bandyopadhyay, "Kaolinite Dehydroxylation Studies on Compact Specimens," M.S. Thesis, Univ. of Calif., Berkeley, Dec. 1970 (UCRL-20393) .

13. Elizabeth A. Wood, "Polymorphism in Potassium Niobate, Sodium Niobate, and other $\mathrm{ABO}_{3}$ Compounds," Acta. Cryst., 4 47 [7 353-62 (1951).

14. W. D. Kingery, "Densification During Sintering in the Presence of a Liquid Phase. I. Theory," J. Appl. Phys.,, 30 [3] 301-6 (1959).

15. Gary Alan Pryor, "Impurity Effects in Sintering of Lead Zirconate Titanate," M.S. Thesis, Univ. of Calif., Berkeley, 1968 (UCRL-18191). 


\section{LEGAL NOTICE}

This report was prepared as an account of work sponsored by the United States Government. Neither the United States nor the United States Atomic Energy Commission, nor any of their employees, nor any of their contractors, subcontractors, or their employees, makes any warranty, express or implied, or assumes any legal liability or responsibility for the accuracy, completeness or usefulness of any information, apparatus, product or process disclosed, or represents that its use would not infringe privately owned rights. 